\title{
Attitudes and Perceptions of Egyptian EFL Post-Graduate students towards Information and Communication Technology (ICT) in Terms of Gender, Geographical Location, and Employment Status

\author{
Dr. Ali Ahmed Amer
}

\section{Abstract :}

Information and communication technology (ICT) has widely spread in all the fields of life including education. The inclusion of ICT in teaching and learning has become a necessity to cope with the latest technological developments and to improve the quality of the educational system of any society. Accordingly, this study aimed to explore the overall attitudes of two hundred (100 males and 100 females studying at four centers, two in Upper Egypt and two in Lower Egypt) Egyptian EFL post-graduate students enrolled at the Educational Qualification Diploma organized by the Faculty of Education, Al-Azhar University, towards ICT and their perceptions of four variables: computer attributes, perceptions of computer relevance to the Egyptian society and schools, computer competence, and computer access, and, then, analyze them in terms of gender, geographical location, and employment status. Findings revealed that students as a one group have positive attitudes toward ICT, positive perceptions of computer attributes and relevance, but with a low level of computer competence due to the existence of some barriers such as lack computer sets, lack of software, lack of training, lack of technical support, lack of ample time, and low income. Besides, results indicated that most of students get computer access at home on their own, half of them get access at school, and a few students get access at Internet cafes. The study also indicated that gender is an insignificant factor regarding students' attitudes towards ICT and their perceptions of computer attributes, relevance to Egyptian society and school, and competence. As far as the geographical location is concerned, the study revealed significant differences in terms of attitudes towards ICT and computer competence in favor of Lower Egyptian students and insignificant differences in terms of computer attributes and relevance. Finings also showed that the employment status of participants is insignificant in terms of attitudes towards ICT and perceptions of computer attributes and relevance and significant in terms of computer competence in favor of unemployed students.

Key words: Teacher attitudes ; Teacher perceptions ; ICT in education ; EFL ; Higher education

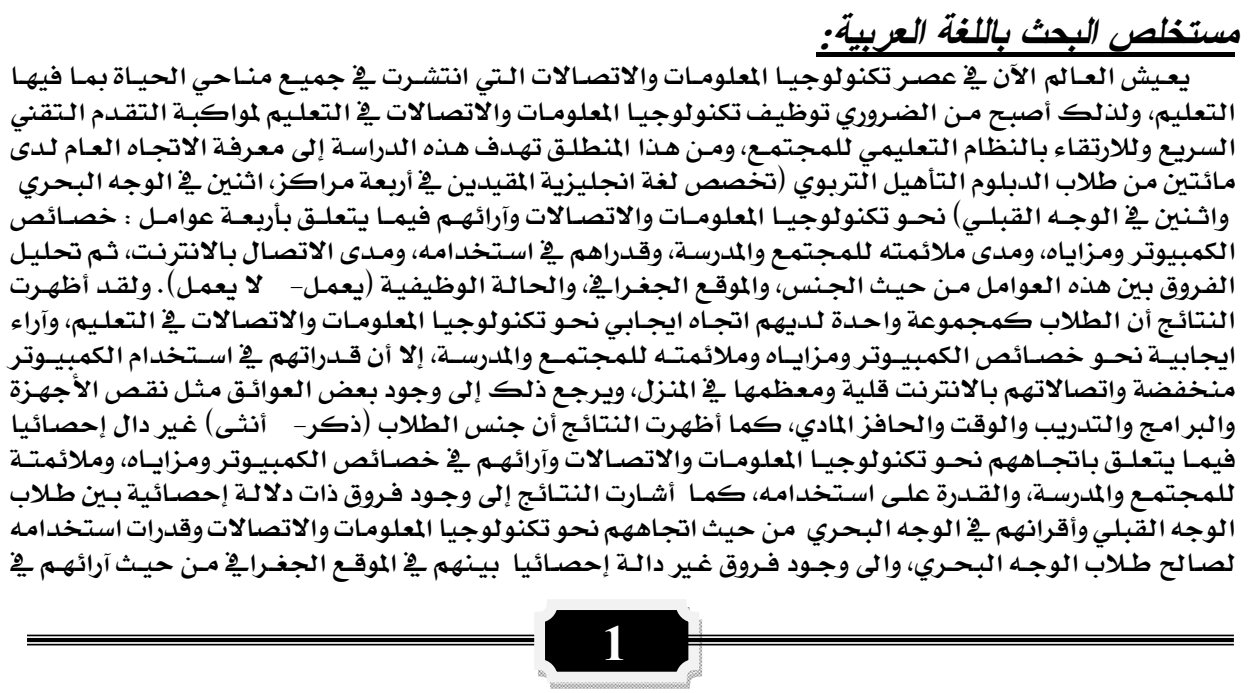




\section{Number 29 , Part 3, September , 2012}

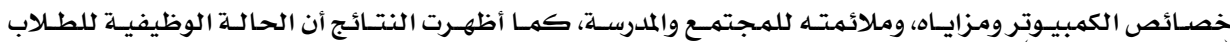

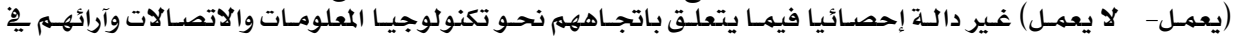

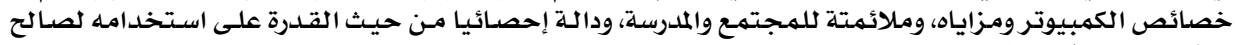

\section{Introduction :}

الطلاب الذين لا يعملون.

The traditional concept of literacy refers to a person's ability to read, write, and make simple arithmetic processes such as addition and subtraction. With the advent of the digital age and the revolution in information and communication technologies (ICTs) such as the internet, this traditional concept of literacy has been superseded and transformed into new forms of literacy (Martin, 2005 ; Grace and Harris, 2012). Those who cannot use the computer or communicate via the Internet will find it difficult to get a job easily or satisfy their ambition or excel in their professions.

Information and communication technology (ICT) has widely spread in all the fields of life including education. The inclusion of ICT in teaching and learning has become a necessity to cope with the latest technological developments and to improve the quality of the educational system of any society (Galbahar and Guven, 2008). For a long time, teachers, textbooks, and blackboards have been the most prominent components of the teaching and learning process. The classrooms of today can be equipped with technological devices such as the Internet, projectors, data shows, and magic boards. This means that ICT has made a change in the teacher's role to match the latest technological developments. The teacher is no longer the main source of or transformer of information, but a facilitator and evaluator of information. Teachers and learners have now to be trained into how to access, gather, store, analyze, transmit, evaluate, and present information (Demirci, 2009).

This significant change in the teacher's role has made it necessary to investigate the attitudes and perceptions of teachers regarding ICT importance and use to society in general and education in particular. This will help in determining how teachers look at ICT, to what extent they use it in the classroom, and what obstacles can hinder the use of ICT in education. Positive attitudes and perceptions of teachers towards ICT importance and use will make their profession more interesting and satisfying, motivate them to achieve higher levels of productivity, and, hence, enhance the teaching and learning process. The development of teachers' positive attitudes toward ICT is a key factor not only for enhancing computer integration but also for avoiding teachers' resistance to computer use (Watson, 1998). Previous research suggests that teachers' attitudes toward computer technologies are also related to teachers' computer competence. Some studies showed that teachers' 
computer competence is a significant predictor of their attitudes toward computers. Berner (2003) and Al-Oteawi (2002) found that most teachers who hold negative or neutral attitudes toward the use of ICT in education lack knowledge and skill about computers. Besides, some studies examining computer attitudes have also reported a significant association between computer access and teachers' attitudes toward computers (Pelgrum, 2001). This study, therefore, is an attempt to identify the attitudes and perceptions towards ICT importance and use of Egyptian EFL and Geography students enrolled at the Educational Qualification Diploma (target population) that is organized and executed by the Faculty of Education (FOE) in Cairo, Al-Azhar University, Egypt.

\section{Attitude and Perception Defined:}

An attitude is defined as the way a person views something or tends to behave towards it, often in an evaluative way (Collins English Dictionary, 1998, p.97). An attitude is also defined as a psychological tendency that is expressed by evaluating a particular entity with a degree of favor or disfavor (Hogg and Vaughan, 2005, p.150). Moreover, an attitude means a relatively enduring organization of beliefs, feelings, and behavioral tendencies towards socially significant objects, groups, events or symbols (McLeod, 2009, p.121). In light of these definitions, an attitude can be defined as a predisposition or tendency to respond positively or negatively to a certain idea or object or individual or situation. It influences a person's choice of actions and responses to challenges, incentives, and rewards. Hence, persons' attitudes towards ICT significance and use greatly affect ICT employment in teaching and learning. A person who has a negative attitude towards ICT cannot be successful in achieving this objective as teachers' attitudes towards ICT shape not only their own ICT experiences but also the experiences of the students they teach. In this study, attitudes refer to the favorable or unfavorable beliefs and feelings of the students enrolled at the Educational Diploma organized by the FOE, Al-Azhar University, towards ICT benefits and use in education.

Perception, on the other hand, is defined as the process by which an organism detects and interprets information from the external world by means of sensory receptors (Collins English Dictionary, 2000, p.1151). This definition is in consonance with that provided by Pickens (1998, p.43) considering perception as the process by which organisms interpret and organize sensation to produce a meaningful experience of the world. Johns and Saks (2010) similarly define perception as the process of interpreting the messages of our senses to provide order and meaning to the environment. This means that perception is conscious or unconscious state of awareness or understanding of one' surroundings 


\section{Number 29 , Part 3, September , 2012}

and this state exists within the mind and is formed through sensory signals stimulated by current conditions, expectations, and past experiences and memories. In this study, perception is used to identify how the target population view and look at computer attributes, relevance to Egyptian society and schools, and competence. Attitudes and perceptions are closely related to each other in the sense that perception is the human subjective experience of information provided by the senses whereas attitude is what the individual thinks about the perception. An individual, for instance, faces a stimulus or situation and interprets it into something meaningful to him/her based on prior information or experience. Still, what one interprets may be substantially different from reality. Hence, individuals can select stimuli or hold views that satisfy their immediate needs and may discard the stimuli that may cause them psychological anxiety (Pickens, 1998).

\section{Attitude Components:}

Eagly and Chaiken( 1993), Breckler (1997), Lord (1997), Franzoi (2003), and Barros and Elia (2004) provide three main components for attitude. They are as follows:

- Affective component, which involves a person's feelings and emotions about the attitude object. An example is: I am scared of spiders.

- Behavioral component, which involves the way the attitude a person has influences how he/she acts or behaves. An example is: I will avoid spiders and scream if I see one of them.

- Cognitive component, which involves a person's knowledge or beliefs about the attitude object. An example is: I believe that spiders are dangerous.

The three components appear concomitantly to shape teachers' classroom postures through a direct and indirect interaction between society, school, students, and teachers.

\section{Perception Components:}

Johns and Saks (2010, p.2) state that perception has three components: a perceiver, a target that is being perceived, and some situational context in which the perception occurs. They are illustrated as follows:

- The Perceiver

The perceiver's experiences, motives, and emotions can affect his/her perceptions as follows:

- Experience, in the sense that our past experiences lead us to develop expectations and these affect current perceptions; differences in 
perception caused by experience can lead to problems within organizations.

- Motivational State, in the sense that differences in our needs at a given moment and our motivational state can be a source of conflict within organizations since our motivational states influence our perception and interpretation of events.

- Emotional State, the emotional state refers to the particular emotions that an individual feels at a given time. Emotions such as anger, happiness, or fear can affect our perceptions. In some cases, we employ a perceptual defense which occurs when our perceptual system serves to defend us against unpleasant emotions. In general, we tend to "see what we want to see."

- The Target, meaning that our perceptions are influenced by the target's social status and ambiguity. Ambiguity or lack of information about a target leads to a greater need for interpretation and addition.

- The Situation, in the sense that the context of the situation can greatly influence our perceptions by adding information about the target.

\section{ICT Defined:}

The term ICT is fluid to a number of definitions. Toomey $(2001, p .1)$ define ICT as those technologies that are used for accessing, gathering, manipulating and presenting or communicating information. The technologies could include hardware (e.g. computers and other devices); software applications and connectivity (e.g. access to the Internet; local networking infrastructure; videoconferencing). Khvilon and Patru (2002) define ICT as a full range of computer hardware and software used for gathering, storing, retrieving, processing, analyzing, and transmitting information. Dighe and Reddi (2006) cite the definition provided by the United Nations Development Program as a varied set of tools, applications, and services that are used to produce, store, process, distribute, and exchange information. They include the old ICTs of radio, television, and telephone and the new ones of computers, satellites, and the Internet. Those definitions are in consonance with those of Adeyemo (2010, p.48) and Asabere and Enguash (2012, p.62) that ICT is concerned with the use of computers to convey, store, process, transmit, and retrieve information in all its forms including voice, text, data, graphics, and video. In this study, ICT refers to the use of the computer and the Internet to handle and communicate information for the purpose of teaching and learning. Hence, ICT plays a crucial role in enhancing the educational development of any country. 


\section{ICT Benefits in Education:}

ICT can bring about several benefits to both teachers and learners. Wheeler (2000, p.2), Moore (2005, p.9), Bingimlas (2009, p.236), and Hennessy et al (2010, pp.41-42) provide the following as ICT benefits in education:

- shared learning resources for both teachers and learners,

- promotion of collaborative learning and teamwork to carry out some projects,

- promotion of autonomy in learning when students direct their own studies with the teacher as a guide,

- enhancement of motivation and increase of creative expression,

- transmission of information throughout the school and other surroundings of information such as timetables, news, projects, and evaluation results,

- preparation of teachers and learners for life in the 21st century to face continuous future developments by arming them with the needed ICT competencies and skills,

- enhancement of students' academic achievement and teacher development,

- easiness and excitement of the teaching and learning process,

- increase of teachers' positive towards ICT and their productivity,

- increase in learning retention and recall of previous learning,

- accessability to immediate and steady feedback,

- reduction of teacher and student apprehension to use modern technology,

- increase in making lessons more interesting, enjoyable, diverse, and motivating, and

- extesion of teachers' subject-matter knowledge.

Sansanwal (2009, pp.5-6) states that ICT can be used in teaching at alleducational levels and stages to achieve the following objectives: development of expression power,

- development of reasoning and thinking power,

- development of judgment and decision-making ability,

- development of comprehension speed and vocabulary,

- development of self-concept and value clarification,

- development of proper study habits, and

- development of risk taking capacity and scientific research.

\section{ICT Obstacles in Education}

There are many obstacles that can hinder the application of ICT in education. Moore (2005, p.17), Bingimlas (2009, p.237-240), and Hennessy et al (2010, pp.42-43) provide several obstacles that are summarized in the following points: 


\section{Number 29 , Part 3, September , 2012}

- lack of teacher effective training into how ICT can enhance teaching and learning,

- lack of teacher confidence (techno-phobia),

- lack of teacher competence (ability) to use ICT,

- lack of ample time (school timetable),

- lack of accessibility to resources,

- lack of a national policy to use ICT in education,

- lack of reliable power supply (electricity),

- lack of teacher incentive to use ICT,

- teachers' level of education and computer literacy,

- -shortage of computers in the classroom and efficient maintenance technicians,

- negative attitudes and perceptions of teachers towards ICT and their resistance to change,

- shortage of the software in the mother-tongue (Arabic),

- -confusion that may be caused to students by the wealth of technological facilities,

- some demographic factor such as size, density, and dispersion, and

- some geographical factors such as country size, terrain, and communication.

\section{ICT Competencies Required by Teachers :}

Prestidge and Watson (2001), Gokats et al (2009), and Okigbo (2012) state that teachers working in a media-rich environment are required to:

- recognize the individual learning problems of learners regarding ICT use,

- check the truth of information content offered,

- be able to conduct effective research with the help of the computer,

- be able to use standard software confidently and competently,

- operate computer systems,

- identify legal, ethical, and societal issues related to use of ICT,

- use word processors for personal and institutional purposes,

- use spreadsheets for personal and institutional purposes,

- use ICT for communication,

- use ICT for collecting data,

- use ICT for knowledge management,

- use ICT for decision-making,

- use ICT communication tools to support instruction,

- use ICT to enhance personal and professional development,

- use ICT to support instruction outside the classroom,

- use of ICT to support instruction process in the classroom,

- use computer-aided instruction and materials, 
- use ICT in the assessment process of a course,

- evaluate computer-aided instruction and materials,

- use ICT in the implementation process of a course,

- use ICT in the designing process of a course,

- use ICT in the material development process of a course,

- integrate ICT into courses,

- use hypermedia and multimedia tools to support instruction,

- create and save documents and delete files,

- use virus software, and

- copy, cut, paste, and insert in another location.

Role of ICT in EFL Teaching and Learning :

The use of ICT in the English classroom has added much to the process of EFL teaching and learning. McKnight (2002, p.5) and Becta (2006, p.34) suggest that incorporating ICT into the English classroom can:

- improve writing and reading skills,

- develop speaking and listening skills, and

- support collaboration, creativity, independent learning, and reflection.

As an interactive and collaborative medium, ICT allows responding, composing, and publication to be easily shared and offers students the opportunity to explore the language of texts more creatively and develop as speakers, writers, and readers for an ever widening range of purposes and audiences. ICT can enable students to:

- access information and respond to a wide range of texts,

- organize and present information in a variety of forms,

- broaden the range of audiences for their work,

- compose a wide range of texts for a broad range of purposes,

- identify key characteristics and features of a text, and

- develop understanding of language and critical literacy.

In the publication of texts, the Internet allows publication and collaboration in ways that were previously closed, or too expensive or time-consuming. ICT enhances composing in English by allowing students to:

- plan, draft, revise and edit their own and others' writing using a word processor and other desktop publishing packages,

- share and collaborate in the writing process,

- use hypermedia to write up, lay out, and present their work for publication on the Internet, 
- transform different media into one text,

- email for a range of communication purposes,

- design websites using informative/ persuasive texts,

- publish writing in a variety of forms,

- use video editing programs and programs such as Photo Story, Movie Maker, and animation software packages,

- integrate digital photography and video into their texts

- integrate different media into one text, and

- communicate with a wider group of people in a range of forums (e.g. via e-mail, newsgroups, online conferencing raps) and, hence, promote collaborative learning (McKnight, 2002).

Besides, Hollenbeck \& Hollenbeck (2004, p. 2), Roberts (2005, pp.23), Alabbad (2010, p.4) and Alkahtani, (2011, p. 93) add that with using technology in teaching foreign languages, learners can serve several functions. They are summarized in the following points. Technology can:

- increase interaction with students and with "real life audiences" outside the classroom,

- meet the different learning styles of students,

- make learning authentic through providing students with materials and activities relevant to the real world,

- create positive learning environments that are supportive and open,

- facilitate communication among students and build language skills that students need not only in but also outside the classroom,

- encourage students to be more responsible for their EFL learning,

- increase their confidence and motivate them by providing them with interesting materials,

- promote academic achievement and positive attitudes towards the subject-matter,

- provide students with more exposure to the target language and, hence, facilitate effective communication,

- gather information on the four macro language skills and related areas such as vocabulary and grammar, and

- develop students' ability in writing letters via using e-mail service and develop their fluency in English through chatting even with native speakers.

\section{Previous Related Studies :}

There are many previous studies related the present work of research variables: studies related to the general attitudes and perceptions of teachers towards ICT, studies related to ICT and gender, geographical location, and computer competence, and studies related to ICT and 
employability. Authors, year of publication, and the most relevant findings of the cited previous studies will be displayed in an ascending order from 1999 through 2012 to show how teachers' attitudes and perceptions towards ICT have been developed with the passage of time. Studies published at the same year will be arranged alphabetically:

Kyriakidou et al (1999) compared primary student teachers' attitudes towards ICT use in England and Cyprus. The study showed that the use of computers by primary student teachers in England enhances their attitudes towards ICT and enables them to be competent users of ICT in the classroom. In Cyprus, primary student teachers are much less competent to implement ICT in their professional life though they had positive attitudes towards ICT due to the lack of ICT potentialities.

Albirini (2006) revealed that Syrian in-service EFL teachers' attitudes towards ICT were positive and consequently affected their use of ICT in the classroom.

Jamieson-Proctor et al (2006) indicated that female in-service teachers were significantly less confident than their male counterparts in using ICT with students for teaching and learning. The study also indicated that there was evidence of significant resistance to the use if ICT to align curriculum with new technologies.

Markauskaite (2006) revealed that there were no significant differences between males and females in terms of previous experience with ICT. Sill, males worked with computers significantly more hours per week than females and they were more competent than females in the ICT competencies.

Jae Shin and Bae Son (2007) suggested that EFL teachers had three factors affecting the Internet use in the classroom: teachers' personal interest in Internet use, their abilities to integrate Internet resources in classroom activities, and computer facilities and technical support at schools.

Al-Rabaani (2008) showed that Omani social studies teachers lack computer skills but had positive attitudes towards their application in teaching. The study also showed that these teachers depended on themselves in developing their computer skills and revealed differences in teachers' computer skills and attitudes towards using computers according to the region and stage they teach, but there were no differences according to gender. Results also showed that half of social studies teachers did not know any websites of Social Studies Centers or 
journals either in English or Arabic. It was also found that these teachers did not benefit from information provided by internet search engines because of their lack of skills in using search engines.

Fancovicova and Prokop (2008) indicated that Turkish student teachers' attitudes towards ICT were positive but its use in teaching and learning has been affected by the lack of facilities and the large numbers of students per computer, up to $N=68$ ).

Gulbahar andGuven (2008) study showed that Turkish teachers of social studies were willing to use ICT resources and were aware of its existing potentials but they were facing problems in relation to accessibility to ICT resources and lack of in-service training opportunities.

Teo (2008) revealed no gender or age statistical differences among pre-service teachers on computer attitudes. Still, there were significant differences for computer attitudes in terms of subject areas : humanities, sciences, and languages, and general (primary). The study also showed relevant correlations between years of computer use, level of confidence, and computer attitudes.

Vekiri (2008) investigated gender beliefs about ICT. The study indicated that female teachers tended to be less interested in computers, to have less positive views about their value, and to report more anxiety and less confidence in their computer abilities. This finding affected their current and future academic choices.

Cavas et al (2009) explored that Turkish primary science teachers had positive attitudes towards ICT and that their attitudes did not differ in terms of gender or geographical location but differ regarding age, computer ownership, and computer experience.

Park and Jeong (2009) indicated that Korean in-service teachers of EFL working at secondary schools in Korea had positive and favorable attitudes toward the use of the computers. The study also reported that external factors such as lack of time, insufficient computer facilities, rigid school curricula and textbooks, and lack of administrative support negatively influence the implementation of CALL in the classroom. Internal factors such as teachers' limited computer skills, knowledge about computers and beliefs and perceptions of CALL also seem to significantly affect teachers' decisions on the use of CALL.

Pelegrin and Badia (2009) indicated that gender was not an exclusion factor in the general attitude towards integrating ICT in the classroom 


\section{Number 29 , Part 3, September , 2012}

and towards the consideration of ICT as a tool to facilitate teaching and learning; no significant difference was found between male and female teachers in vocational schools.

Walton et al (2009) revealed that ICT skills are predictor of employment and are associated with higher income and prestige jobs.

Adeyemo (2010) explored that ICT has had a great impact on the teaching and learning of Physics; it makes learning more interesting and motivating to students.

Al-Zaidiyeen et al (2010) revealed that rural secondary school teachers in Jordan had a low level of ICT use for educational purposes though their attitudes towards ICT use were positive. Besides, the study showed a significantly positive correlation between teachers' level of ICT and their attitudes towards ICT use.

Bordbar (2010) indicated that Iranian EFL teachers had positive attitudes towards computer use in the classroom, that teachers who used computer-assisted language learning (CALL) were those who had experience prior to teaching, and that lack of time and resources prohibit CALL use in the classroom.

Gillwald et al (2010) yielded the result that women were not equally able to access or use ICT due to factors such as income, education level, and social position. Women were less likely than men to have the necessary electronic skills to use the different technologies optimally.

Awan (2011) found a positive shift in teachers' attitudes towards a received in-service ICT training course and positive attitudes in the use of ICT in teaching. The study recommended more in-service training through computer games for more ICT use in teaching.

Bakr (2011) revealed that Egyptian public school teachers had positive attitudes towards computers and that there were no significant differences in terms of gender or teaching experience.

$H u$ (2011) indicated that initially the majority of Chinese teachers had held positive attitudes towards ICT use in English teaching and the national reform, but their enthusiasm was waning in the light of inadequate support and training. The national reform had, however, stimulated the improvement of ICT competence of both teachers and students. At the same time, it had challenged EFL teachers to adapt to new teaching materials, student-centered classroom teaching and how to guide students in their autonomous learning. 


\section{Number 29 , Part 3, September , 2012}

Kaur(2011) indicated that the positive attitudes of pre-service science teachers encourage them to use ICT in teaching and learning and that lack of facilities at schools and ICT knowledge and skills among teachers represent barriers to ICT use in teaching and learning.

Ozpinar et al (2011) revealed that Turkish mathematics teacher candidates had positive attitudes towards applying ICT in the classroom setting and that there was a significant correlation between attitudes and gender in favor of males.

Panigrahi (2011) found that there was no significant difference between Ethiopian urban senior secondary school teachers' perception and their rural counterparts towards the utilization of ICT, no significant difference between urban male and rural male teachers' perception, and no significant difference between urban female and rural female teachers' perception towards ICT utilization.

Rahimi and Yanollahi (2011) revealed that digital portable devices were used more than computer or network applications/tools in English classes and teachers used technology teaching oral skills. It was also found that ICT use correlated inversely with teachers' age, years of teaching experience, and computer anxiety. ICT use was found to be positively and significantly related to teachers' academic disciplines, computer ownership, computer literacy, and use while ICT use was not related to attitude and gender.

Sarfo et al (2011) indicated that high school students' general attitudes towards ICT did not differ in terms of gender and that students from urban areas had more positive attitudes towards ICT than those from rural areas.

El-Saadani (2012) indicated that there was no significant difference between male and female Egyptian teaching staff members at Higher Education Institutes as regard to attitudes towards ICT.

Capan (2012) reveals a positive inclination towards benefitting from computers in EFL classrooms. The results also indicate that computer use was considered highly advantageous despite the perceived complexity of using them in the classroom. Moreover, the study suggested that high computer competence, positive cultural perceptions, and computer accessibility at home and school were crucial factors affecting EFL teachers' attitudes towards computer use.

Mahmoud and Bokhari (2012) revealed that there were gender differences among students at the tertiary level regarding ICT access. 
In light of the review of related literature presented in this study, it could be observed that there are some points of agreement and disagreement among those works concerning the attitudes of pre-service and in-service teachers towards ICT in general and in terms of gender, computer competence and access, geographical location, and employability. Those points of agreement and disagreement are illustrated in the following points:

- All the previous studies related to the attitudes and perceptions of teachers towards ICT proved that teachers had positive attitudes and perceptions towards ICT such as Albirini (2006), Galbhar and Guven (2008), Cavas et al (2009), Park and Jeong (2009), Bordbar, (2010), Bakr, (2011), and Capan, (2012); there is not any study to contradict this finding.

- Although teachers had positive attitudes towards ICT use in teaching and learning, they were not able to put this into action due to the presence of some obstacles such as the lack of facilities, computer access, and necessary training. This inverse correlation between the positive attitude towards ICT and its use in teaching and learning is indicated in the studies of Kyriakidou (1999), Fancovcova (2008), Gulbahar and Guven (2008), Demirci (2009), Park and Jeong (2009), Bordbar (2010), Gillwald et al (2010), Kaur (2011), and Hu (2011).

- In terms of investigating the correlation between gender and ICT, some studies found no significant difference (no difference between males and females regarding ICT) such as Markauskaite (2006), AlRabaani (2008), Toe (2008), Cavas et al (2008), Pelegrin and Badia (2009), Bakr (2011), Rahimi and Yanollahi (2011), Sarfo et al (2011), and EL-Saadani (2012). Still, some other studies did not go in consonance with this finding such as Jamieson-Proctor et al (2006), Vekiri (2008), Gillwald et al (2010), Ozpinar et al (2011), and Mahmoud and Bokhari (2011).

- Some studies found no difference between age and ICT use such as Toe (2008), and Pelegrin and Badia (2009). Still, some other studies contradicted this finding such as Cavas et al (2009) and Rahimi and Yanollahi (2011) in the sense that there was significant difference between age and ICT use.

- As far as the relation between geographical location and ICT is concerned, some studies revealed that there were significant differences such as Kyriakidou (1999), Al-Raabani (2006), AlZaidiyeen et al (2010), and Sarfo (2011) unlike the study of Panigrahi (2011) that showed that there were no differences.

- Walton et al (2009) indicated that there was a positive correlation between ICT literacy/competence and employability. 
- There was a positive correlation between positive attitudes towards ICT and ICT competence and its application in teaching and learning (Watson, 1998 ; Oteawi, 2002 ; Berner, 2003 ; Toe, 2008).

- There was a positive correlation between positive attitudes towards ICT and computer access (Pelgrum, 2001) and ICT skills and higher income and prestigious jobs (Walton, 2009).

Hence, it can be concluded that results of the cited works of research contradict each other and the issues regarding the attitudes and perceptions of teachers towards ICT in terms of gender, geographical location, computer competence are still controversial and need more investigation, and the present study is a humble endeavor in this direction.

\section{Need for the Study:}

In a digital age with a revolution in ICT like the one we live in, teachers who generally have negative attitudes or perceptions towards ICT are more unwilling and less motivated to use ICT in the teaching/learning situation than those who have positive attitudes or perceptions. So, for the professional growth of teachers and improvement in education, the attitudes and perceptions held by teachers towards ICT attributes and relevance are crucial. Teachers' positive attitudes and perceptions towards ICT make teaching easier, more satisfying, and professionally rewarding. Their negative attitudes and perceptions towards ICT make teaching traditional, less interesting and motivating and influence the behaviors of their students.ICT technologies are useful teaching tools that can enhance ways of teaching by offering students a variety of inputs and expanding students' learning experiences in real and authentic contexts. Thus, effective and productive learning on the part of students can be achieved only by teachers with favorable and desirable attitudes and perceptions towards ICT. Hence, the attitudes and perceptions of EFL post-graduate students (target population) enrolled at the Educational Qualification Diploma organized by the FOE, Al-Azhar University, form the major variable of this work of research.

\section{Statement of the problem:}

Al-Azhar, as the main religious institution in Egypt, is completely responsible for the supervision of the primary, preparatory, and secondary institutes that spread at the rural and urban zones of all the Egyptian Governorates. Thousands of the teachers who work at these educational institutes graduated at faculties such Arts, Science, Commerce, Arabic Language, Languages and Translation, either at AlAzhar University or the other universities in Egypt. This means that in their undergraduate disciplines, they studied the content (academic) 


\section{Number 29 , Part 3, September , 2012}

component, but did not study the educational or Islamic ones. So, AAzhar administration decided to educationally and Islamically qualify those teachers for their professional development to enhance their teaching performance by organizing the Educational Qualification Diploma under the complete supervision of the FOE, Al-Azhar University, in Cairo. The diploma started four years ago and was confined to the teachers who work at Al-Azhar religious institutes, but now the diploma is open to all graduates at the other Egyptian universities.

Hence, the problem of this study lies in the unsatisfactory employment of ICTs as educational tools and, then, in identifying the attitudes and perceptions of the target population, either in-service (employed) or preservice (unemployed), towards ICT and compare them to the contradicting results of the cited previous studies of teachers' attitudes towards ICT in terms of gender, geographical location, and employment status.

\section{Purpose of the study:}

The present study aims to identify the overall attitudes of target population (TP) enrolled at the Educational Qualification Diploma organized by the FOE, Al-Azhar University, towards ICT, their perceptions of computer attributes as an educational tool, computer relevance to the Egyptian society and schools, computer competence, and computer access, analyze them in terms of gender, geographical location, and employment status (employed or unemployed), and show how their attitudes and perceptions are or are not in consonance with the results of contradicting previous related studies.

\section{Questions of the Study:}

The present study seeks to find answers to the following questions:

- What are the TP overall attitudes towards ICT in education?

- What are the TP overall perceptions of computer attributes?

- What are the TP overall perceptions of the cultural relevance of computers to Egyptian society and schools?

- What are the TP levels of their computer competence?

- What is the TP extent of computer access at specific places such as home, school, and café?

- Are there any differences between male TP and their female counterparts regards to their attitudes towards ICT in education and their perceptions of computer attributes, relevance to Egyptian society and schools, and levels of competence? 
- Are there any differences between Upper Egypt TP and their Lower Egypt counterparts regards to their attitudes towards ICT in education and their perceptions of computer attributes, relevance to Egyptian society and schools, and levels of competence?

- Are there any differences between employed TP and their unemployed counterparts regards to their attitudes towards ICT in education and their perceptions of computer attributes, relevance to Egyptian society and schools, and their levels of competence?

\section{Sample of the Studv :}

Using the stratified random technique, the sample of the study was selected. It comprised two hundred EFL students enrolled at the Educational Qualification Diploma supervised by the FOE, Al-Azhar University, in four Egyptian governorates, two in Upper Egypt (Luxor and Aswan) and two in Lower Egypt (Mansoura and Monefiya) during the academic year 2011-2012. Student numbers are presented in the following table:

Table (1): Sample categories and numbers

\begin{tabular}{|c|c|c|}
\hline Sample variable & Variable type & Number \\
\hline \multirow{2}{*}{ Gender } & Male & 83 \\
& Female & 117 \\
\hline Geographical location & Upper Egypt & 100 \\
& Lower Egypt & 100 \\
\hline \multirow{2}{*}{ Employment status } & Employed & 114 \\
& Unemployed & 86 \\
\hline Total & & 200 \\
\hline
\end{tabular}

\section{Instrument of the Study:}

The present work of research employed one main instrument in the form of a questionnaire developed by Albirini (2006) and adapted by the researcher. The researcher preferred this instrument as it suits the purpose of the study and was originally designed for the Syrian teachers who resemble the TP circumstances concerning the professional, social, economical, cultural, and religious aspects. The questionnaire measures the overall attitudes of the TP towards ICT and their perceptions of computer attributes, relevance to society and schools, competence, and access in terms of gender, geographical location, and employment status. The questionnaire consists of six sections. Section One includes 20 items to measure the TP attitudes towards ICT. The items were designed to measure the affective domain of computer attitude (items 16), the cognitive domain (items 7-15), and behavioral one (items 15-20). Section Two consists of eighteen items to measure the TP perceptions of computer attributes. Participants were asked to respond to the relative advantage of computers (items 1-5), their compatibility with teachers' current practices (items 6-10), their simplicity/non-complexity (items 
11-14), and their observations of computer use in teaching and learning (items 15-18). Section Three includes sixteen items to measure the TP perceptions of computer relevance to the Egyptian society and schools. From sections one to three, subjects had to respond to the questionnaire by ticking the column that expresses their viewpoint concerning each item. Response levels (following Likert five-point scale) were: Strongly Agree (SA), Agree (A), Neutral (N), Disagree (D), and Strongly Disagree (SD).

Section Four comprises fifteen items to measure the TP perceptions of copmuter competence. Subjects had to respond to those items by indicating the level of their computer competence ranging from no competence to much competence (four levels). Section Five includes three items to measure the TP frequency rates and places of computer access. Subjects had to respond by identifying the frequency rates of computer access ranging from daily access to never access (five levels) at three specific places ( home; school ; Internet café). Moreover, a demographic information segment (Section Six) is added to the questionnaire. This segment includes two questions related to students' gender and geographical location of the educational qualification center they study at. Students had to respond to those questions by checking the appropriate boxes (See Appendices A and B).

The questionnaire was adapted in the sense that the words "Arab and Syrian" were replaced by the word "Egyptian" in some items, and the number of items of Section Six was reduced from eight into two ones in both the English and Arabic versions. After adaptation, the Arabic version was administered to the target population to avoid any misunderstanding that might have happened if the questionnaire was administered in English. Four hundred copies of the questionnaire were distributed to students on four different occasions, three hundred and fifty-five were collected, and only two hundred copies were selected as they were the correctly completed ones.

For reliability purposes, the study made use of the report given by Albirini (2006). According to the scale developed by Albirini, the Cronbach-Alpha coefficients for the first four sections were found to be $0.90,0.86,0.76$, and 0.94, respectively. The computer access section consisted of three statements that took into account possible locations where computers might be available for use by EFL students: at home, at school, and other places. Demographic variables were quantified by individual scores on two items. The responses to the two items were treated separately as descriptive information that was correlated with the attitudes toward ICT. 


\section{Procedure:}

Out of thirteen centers responsible for the administration of the Educational Qualification Diploma under the complete supervision of the FOE, Al-Azhar University, four centers were selected, two in Upper Egypt (Luxor and Aswan) and two in Lower Egypt (Mansoura and Monefiya). Those centers were chosen as the researcher taught the TP during the academic year 2011-2012. This made it easier for the safety and accuracy of administration, which was carried out under the supervision of the researcher in the month of April, 2012 on four different occasions.

\section{Hypotheses of the Study:}

The present study seeks to verify (test) the following hypotheses:

- The overall attitude of the TP towards ICT and their perceptions of computer attributes and relevance to Egyptian society and schools is significantly positive.

- The TP computer competence ranges between "Little" to "No" Competence.

- The TP computer access ranges between "Two to three times a week" access to "Never" access.

- There are statistically significant differences between the mean scores of the computer attitudes, attributes, relevance to society and schools, and competence of female students and the mean scores of their male counterparts in favor of male students.

- There are no statistically significant differences between the mean scores of the computer attitudes, attributes, relevance to society and schools, and competence of Upper Egypt students and the mean scores of their Lower Egypt counterparts.

- There are no statistically significant differences between the mean scores of the computer attitudes, attributes, relevance to society and schools, and competence of employed students and the mean scores of their unemployed counterparts.

\section{Results and Discussion:}

In order to answer the study questions and to verify the raised hypotheses, the raw scores of respondents on the study instrument were treated using the computerized statistical package for social sciences (SPSS) to:

- calculate the frequency $(F)$ and percentage $(P)$ values for all the items of the five sections of the questionnaire (attitudes towards ICT, perceptions of computer attributes, relevance to society and schools, level of competence, and computer access.

- calculate the T-values for the study binary variables: males/females ; Upper Egypt/Lower Egypt ; employed/ unemployed. 
Regarding the first question of the study (What are the TP overall attitudes towards ICT in education?), results are illustrated in the following table:

Table (2): $F$ and $P$ values of the TP overall attitudes towards ICT

\begin{tabular}{|c|c|c|c|c|c|c|c|c|c|c|}
\hline Item & \multicolumn{2}{|c|}{ SD } & \multicolumn{2}{|r|}{$\mathrm{D}$} & \multicolumn{2}{|r|}{$\mathrm{N}$} & \multicolumn{2}{|c|}{$\mathrm{A}$} & \multicolumn{2}{|c|}{$\mathrm{SD}$} \\
\hline 1 & 1 & $0.5 \%$ & 18 & $9.5 \%$ & 3 & $1.05 \%$ & 65 & $32.5 \%$ & 113 & $56.5 \%$ \\
\hline 2 & 80 & $40.0 \%$ & 79 & $39.5 \%$ & 9 & $4.5 \%$ & 16 & $8.0 \%$ & 16 & $8.0 \%$ \\
\hline 3 & 7 & $3.5 \%$ & 25 & $12.5 \%$ & 5 & $2.5 \%$ & 31 & $15.5 \%$ & 132 & $66.5 \%$ \\
\hline 4 & 60 & $30.0 \%$ & 2 & $1.0 \%$ & 89 & $44.5 \%$ & 49 & $24.5 \%$ & 60 & $30.0 \%$ \\
\hline 5 & 3 & $1.5 \%$ & 14 & $7.0 \%$ & 11 & $5.5 \%$ & 33 & $16.5 \%$ & 139 & $69.5 \%$ \\
\hline 6 & 0 & $0 \%$ & 18 & $9.0 \%$ & 19 & $9.5 \%$ & 115 & $57.5 \%$ & 48 & $24.0 \%$ \\
\hline 7 & 23 & $11.5 \%$ & 14 & $7.0 \%$ & 3 & $1.5 \%$ & 4 & $2.0 \%$ & 156 & $78.0 \%$ \\
\hline 8 & 0 & $0 \%$ & 40 & $20.0 \%$ & 5 & $2.5 \%$ & 111 & $55.5 \%$ & 44 & $22.0 \%$ \\
\hline 9 & 8 & $4.0 \%$ & 19 & $9.5 \%$ & 1 & $0.5 \%$ & 55 & $27.5 \%$ & 117 & $58.5 \%$ \\
\hline 10 & 0 & $0 \%$ & 25 & $12.0 \%$ & 6 & $3.0 \%$ & 105 & $52.5 \%$ & 64 & $32.0 \%$ \\
\hline 11 & 3 & $1.5 \%$ & 13 & $6.5 \%$ & 1 & $0.5 \%$ & 37 & $18.5 \%$ & 164 & $73.0 \%$ \\
\hline 12 & 33 & $16.5 \%$ & 26 & $13.0 \%$ & 2 & $1.0 \%$ & 13 & $6.5 \%$ & 126 & $63.0 \%$ \\
\hline 13 & 0 & $0 \%$ & 47 & $23.5 \%$ & 12 & $6.0 \%$ & 86 & $43.5 \%$ & 55 & $27.5 \%$ \\
\hline 14 & 37 & $18.5 \%$ & 13 & $6.5 \%$ & 5 & $2.5 \%$ & 37 & $18.5 \%$ & 108 & $54.0 \%$ \\
\hline 15 & 1 & $0.5 \%$ & 52 & $26.0 \%$ & 13 & $6.5 \%$ & 69 & $34.5 \%$ & 65 & $32.5 \%$ \\
\hline 16 & 35 & $17.5 \%$ & 60 & $30.0 \%$ & 3 & $1.5 \%$ & 55 & $27.5 \%$ & 47 & $23.5 \%$ \\
\hline 17 & 24 & $12.0 \%$ & 14 & $7.0 \%$ & 2 & $1.0 \%$ & 27 & $13.5 \%$ & 133 & $66.5 \%$ \\
\hline 18 & 96 & $26.5 \%$ & 53 & $26.5 \%$ & 2 & $1.0 \%$ & 16 & $8.0 \%$ & 33 & $16.5 \%$ \\
\hline 19 & 21 & $10.5 \%$ & 2 & $1.0 \%$ & 1 & $0.5 \%$ & 15 & $7.5 \%$ & 161 & $80.0 \%$ \\
\hline 20 & 0 & $0 \%$ & 9 & $4.5 \%$ & 40 & $20.0 \%$ & 70 & $35.0 \%$ & 81 & $40.5 \%$ \\
\hline
\end{tabular}

Section One (participants' attitudes towards ICT) comprises twenty items divided into three subsections: affective, cognitive, and behavioral domains of attitude. The affective domain of students' attitude is presented in six items (1-6). As is clear in Table (2), percentages show that the responses of the TP to the affective domain of attitude towards ICT are positive to four items $(1 ; 2 ; 3 ; 5)$ with an overall $P(66.67 \%)$. This finding means that $81.5 \%$ of the sample subjects are glad that there are more computers these days, $89 \%$ of students believe that computers do not scare them at all, $86 \%$ of participants believe that using computers is enjoyable, and that $79.5 \%$ of students do not agree that computers make them feel uncomfortable. On the contrary, responses of the TP to the affective domain of attitude towards ICT are negative to two items $(4 ; 6)$. This means that $81.5 \%$ of students dislike using computers in teaching and that $69 \%$ of them do not like talking with others about computers. In brief, regarding students' responses to this sub-section (the affective side of attitude), there are four positives versus 
two negatives) signaling $66.67 \%$ overall positive agreement to the affective side of attitude towards ICT.

The cognitive domain of students' attitude towards ICT is presented in nine items (7-15). As shown in Table (2), percentages show that the responses of TP to the cognitive domain of attitude towards ICT are positive to five items $(7 ; 9 ; 11 ; 12 ; 14)$ with an overall $P$ of $(55.56 \%)$. This result means that participants agree that computers save time and effort $(80 \%)$, that students must use computers in all subject matters $(85 \%)$, that computers would motivate students do more study $(91.5 \%)$, that computers are a vast and efficient means of getting information (69.5\%), and that computers can enhance students' learning (72.5\%). Besides, results of Table (2) show that the responses of the TP to the cognitive domain of attitude towards ICT are negative to four items ( 8 ; $10 ; 13$; 15) with an overall $P$ of $(44.44 \%)$. This result means that participants agree that schools would a better place without computers $(77.5 \%)$, that learning about computers is a waste of time (84.5\%), that they do not think they would ever need a computer in their classrooms (70.5\%), and that computers do more harm than good (67\%). In brief, regarding students' responses to this sub-section (the cognitive side of attitude), there are five positives versus four negatives) indicating $55.56 \%$ overall positive agreement to the cognitive side of attitude towards ICT.

The behavioral domain of students' attitudes towards ICT is presented in five items (16-20). As is clear in Table (2), the responses of the TP to the behavioral domain of attitude towards ICT are negative to two items $(16 ; 20)$ with a $P$ of $(40 \%)$ and positive to three ones $(17 ; 18 ; 19)$ with a $P$ of $(60 \%)$. This finding means that means that $51 \%$ of participants agree that they would rather do things by hand than with a computer and $75.5 \%$ of them agree that they have no intention to use computers in the near future. This finding also means that $80 \%$ of students agree that if they had the money, they would buy a computer, that $74.5 \%$ of them do not agree that they avoid computers as much as possible and that $88 \%$ agree that they would like to learn more about computers. In brief, regarding students' responses to this sub-section (the behavioral side of attitude), there are three positives versus two negatives) indicating $60 \%$ overall positive agreement to the behavioral side of attitude towards ICT.

In sum, $60.74 \%$ of students' responses to all the first section items prove positive attitudes towards ICT as regards the affective, cognitive, and behavioral sides of attitude. Teachers' attitudes are recognized as vital factors for the successful implementation of ICTs in education ( Watson, 1998). Participants' attitudes in this study are positive. They 
accept the rationale to introduce ICTs in their general life and profession once barriers and obstacles are removed and incentives are guaranteed. This above-average percentage can be attributed to the presence of some barriers and obstacles such as lack of facilities and potentialities, lack of previous experience, and lack of training, lack of time, and lack of ample income. The last factor (lack of money) is the most crucial to Egyptians concerning the formulation of their attitudes towards ICT. The dream of any Egyptian university graduate either employed or not is to have an income that can meet the basic needs of life such education, home, health, food, and clothes. No money is left to buy a computer and afford for its accessories. Even for those who can afford for it do not think that ICT cannot be ideally applied in teaching and learning for the previously reasons nationwide. Besides, in most schools, there are no well-furnished rooms for teachers, no healthy bathrooms for male and female teachers, classrooms are overcrowded, teachers encounter much insult from students' parents for trivial reasons, and teachers cannot punish students who violate rules and ethics. In an atmosphere like this, how can teachers even those who have positive attitudes towards ICT innovate to convert ICTs into a reality in their classrooms. This result of the inverse correlation between the positive attitude towards ICT and its use in teaching and learning is in consonance with the studies of Kyriakidou (1999), Albirini (2006), Fancovcova (2008), Gulbahar and Guven (2008), Cavas et al (2009), Demirci (2009), Park and Jeong (2009), Bordbar (2010), Gillwald et al (2010), Bakr, (2011), Kaur (2011), Hu (2011), and Capan, (2012).

Regarding the second question of the study (What are the TP overall perceptions of computer attributes?, results are illustrated in the following table:

Section Two ( participants' perceptions of computer attributes) consists of eighteen items divided into four subsections: computer advantages, computer compatibility with teachers' current practices, computer simplicity/non-complexity, and obsrvability ('students' observations of computer use). Computer advantages are presented in five items (1-5). As is clear in Table (3), percentages show that the responses of the TP to computer advantages are positive to three items $(1 ; 2 ; 4)$ with a $p$ of $(60 \%)$. Participants strongly agree and agree that computers will improve education (91.5\%), offers real advantages over the traditional methods of instruction (86.5\%), and make the learning of the subject matter more interesting (83\%). On the contrary, their responses are negative to two items $(3 ; 5)$ with a pof $(40 \%)$. Participants agree that computers cannot improve the quality of students' learning (54\%) and are not useful for language learning 
( $70.5 \%)$. In short, regarding students' responses to this sub-section (computer advantages), there are three positives versus two negatives) indicating $60 \%$ overall positive agreement to the perception of ICT.

Table(3): $F$ and $P$ values of the TP overall perceptions

\begin{tabular}{|c|c|c|c|c|c|c|c|c|c|c|}
\multicolumn{10}{c|}{ of computer attributes } \\
\hline Item & \multicolumn{2}{|c|}{$\mathrm{SD}$} & \multicolumn{2}{|c|}{$\mathrm{D}$} & \multicolumn{2}{|c|}{$\mathrm{N}$} & \multicolumn{2}{|c|}{$\mathrm{A}$} & \multicolumn{2}{|c|}{ SA } \\
\hline 1 & 7 & $3.5 \%$ & 9 & $4.5 \%$ & 1 & $0.5 \%$ & 26 & $13.0 \%$ & 157 & $78.5 \%$ \\
\hline 2 & 12 & $6.0 \%$ & 12 & $6.5 \%$ & 3 & $1.5 \%$ & 62 & $31.0 \%$ & 111 & $55.5 \%$ \\
\hline 3 & 0 & $0 \%$ & 81 & $40.5 \%$ & 11 & $5.5 \%$ & 84 & $42.0 \%$ & 24 & $12.0 \%$ \\
\hline 4 & 11 & $5.5 \%$ & 17 & $8.5 \%$ & 6 & $3.0 \%$ & 26 & $13.0 \%$ & 140 & $70.0 \%$ \\
\hline 5 & 2 & $1.0 \%$ & 27 & $15.0 \%$ & 30 & $15.0 \%$ & 70 & $35.0 \%$ & 71 & $35.5 \%$ \\
\hline 6 & 3 & $1.5 \%$ & 72 & $36.0 \%$ & 18 & $9.0 \%$ & 94 & $47.0 \%$ & 13 & $6.5 \%$ \\
\hline 7 & 3 & $1.5 \%$ & 20 & $10.0 \%$ & 33 & $16.5 \%$ & 75 & $37.5 \%$ & 69 & $34.5 \%$ \\
\hline 8 & 3 & $1.5 \%$ & 53 & $26.5 \%$ & 26 & $13.0 \%$ & 78 & $39.5 \%$ & 40 & $20.0 \%$ \\
\hline 9 & 0 & $0 \%$ & 10 & $5.0 \%$ & 19 & $9.5 \%$ & 106 & $53.0 \%$ & 65 & $35.5 \%$ \\
\hline 10 & 9 & $4.5 \%$ & 20 & $10.0 \%$ & 4 & $2.0 \%$ & 86 & $43.0 \%$ & 81 & $40.5 \%$ \\
\hline 11 & 40 & $20.0 \%$ & 97 & $48.5 \%$ & 19 & $9.5 \%$ & 30 & $15.0 \%$ & 14 & $7.0 \%$ \\
\hline 12 & 15 & $7.5 \%$ & 39 & $19.5 \%$ & 27 & $13.5 \%$ & 94 & $47.0 \%$ & 25 & $12.5 \%$ \\
\hline 13 & 44 & $22.0 \%$ & 79 & $39.5 \%$ & 19 & $9.5 \%$ & 41 & $20.5 \%$ & 17 & $8.5 \%$ \\
\hline 14 & 6 & $3.0 \%$ & 25 & $12.5 \%$ & 18 & $9.0 \%$ & 73 & $36.5 \%$ & 78 & $50.0 \%$ \\
\hline 15 & 7 & $3.5 \%$ & 44 & $22.0 \%$ & 14 & $7.0 \%$ & 85 & $42.5 \%$ & 50 & $25.5 \%$ \\
\hline 16 & 2 & $1.0 \%$ & 15 & $7.5 \%$ & 5 & $2.5 \%$ & 56 & $28.0 \%$ & 122 & $61.0 \%$ \\
\hline 17 & 2 & $1.0 \%$ & 55 & $27.5 \%$ & 13 & $6.5 \%$ & 63 & $31.5 \%$ & 67 & $33.5 \%$ \\
\hline 18 & 28 & $14.0 \%$ & 24 & $12.0 \%$ & 16 & $8.0 \%$ & 88 & $44.0 \%$ & 44 & $22.0 \%$ \\
\hline
\end{tabular}

As for computer compatibility with teachers' current practices (items 6-10), results of Table (3) indicate that responses of the TP are positive to three items $(7 ; 9 ; 10)$ with $60 \%$ : participants believe that computers fit well into curriculum goals (72\%), suit students' learning preferences, $(85.5 \%)$, and suit language learning activities (83.5\%). On the contrary, their responses to two items $(6 ; 8)$ are negative with a $P$ of $(40 \%)$ : they believe that computers have no place at schools (53.5\%) and that class time is too limited for computer use (59\%). In short, regarding students' responses to this sub-section (computer compatibility with teachers 'current practices), there are three positives versus two negatives) indicating $60 \%$ overall positive agreement to the perception of ICT. Besides, insufficient class time and budget represent two major obstacles to the use of ICT in teaching.

Concerning computer simplicity/non-complexity (items 11-14), results of Table (3) explore that responses of the TP are positive to all the four items with 100\%: participants find it easy to learn to use the computer 
in teaching (68.5\%), to understand the basic functions of computers $(59.5 \%)$, to hold the belief that computers do not complicate their task in the classroom (61.5\%), and to learn to operate a computer $(75.5 \%)$.

Concerning the TP observations related to computer use (items 1518), results of Table (3) find that responses of the TP are negative to two items $(15 ; 17)$ with $50 \%$ : students have never seen computers at work (67.5\%) or computers being used as an educational tool (65\%). Still, their responses to the other two items $(16 ; 18)$ are positive with $50 \%$ :

they believe that computers proved to be effective learning tools worldwide (89\%) and that they have seen some Egyptian teachers use computers for educational purposes (66\%).

In general, results of Table (3) mean that (67.50\%) of the responses of the TP are positive regarding computer attributes and that (32.50) of their responses are negative. The positive responses are related to the general items of computer attributes but the negative ones are related to the application of ICT in teaching and learning due the presence of some barriers and obstacles as stated earlier in the discussion of the question one results. The presence of some barriers and obstacles may affect their perceptions of the use of ICT in teaching and learning and this goes in line with some previous studies (Kyriakidou, (1999) ; Fancovcova (2008) ; Gulbahar and Guven (2008) ; Demirci (2009) ; Park and Jeong (2009) ; Bordbar (2010) ; Gillwald et al (2010), Kaur (2011) ; $\mathrm{Hu}$ (2011). Besides, education development and improvement cannot be made with just equipping classrooms with just computer sets, but through a revolutionary change in the structural, pedagogical, and curricular levels (Salamon, 2002).

Regarding the third question of the study (What are the TP overall perceptions of computer relevance to Egyptian society and schools?), results are illustrated in the following table:

Section Three of the study instrument ( cultural perceptions of computer relevance to Egyptian society and schools) includes sixteen items (1-16). Findings of Table (4) show that responses of the TP are positive to nine items $(2 ; 4 ; 6 ; 7 ; 8 ; 9 ; 12 ; 14 ; 16)$ with a $p$ of (56.25\%): participants agree that students need to know how to use computers for their future jobs (64.5), that computers make one earn the respect of others $(81,5 \%)$, that computers will improve their standard of living $(93.5 \%)$, that computers would not hinder Egyptian generations from learning their traditions (88\%), that people who are skilled in computers have privileges not available to others $(83 \%)$, that the increased proliferation of computers will make life easier (77\%), that computers do not diminish people' relationships with each other (77.5),

\section{4}


and that computers should be a priority in education (89.5\%). Besides, participants' response to item ten is neutral (not decisive) with a $p$ of (50\%): computers will increase dependence on foreign countries. On the contrary, their responses to items $(1 ; 3 ; 5 ; 11 ; 13 ; 15)$ are negative with a $P$ of (31.25\%): they believe that computers will not make any difference in their classrooms, schools, or lives (52.5\%), that their students prefer learning from teachers to learning from computers $(59 \%)$, that they need computers that suit better Egyptian culture and identity (90\%), that there are some social issues to be addressed before implementing them in education (78\%), that computers dehumanize society $(77.5 \%)$, and that computers encourage unethical practices $(61 \%)$. In short, regarding students' responses to the items of Section Three, there are nine positives versus six negatives plus one neutral indicating $56.25 \%$ overall positive agreement. In sum, more than half of respondents (61.50\%) agree that ICT is relevant to Egyptian society and schools in that it can, for instance, improve education and standards of life. Still, they need localized ICT versions that suit Egyptian culture and identity, they express their fears of society dehumanization, some social problems, and unethical practices, and that the Egyptian student is closely related to his/her teacher and prefer to receive learning better from him/her teacher than from a computer. Such findings are in congruence with the studies of Albirini (2006), Galbhar and Guven (2008), Cavas et al (2009), Park and Jeong (2009), Bordbar, (2010), Bakr (2011), and Capan (2012). Hence, the first hypothesis of the present study that "the overall attitudes of the TP towards ICT and their perceptions of computer attributes and relevance to Egyptian society and schools are significantly positive" is accepted.

\section{Table (4): $F$ and $P$ values of the TP overall perceptions}

of computer relevance

\begin{tabular}{|c|c|c|c|c|c|c|c|c|c|c|}
\hline Item & \multicolumn{2}{|c|}{ SD } & \multicolumn{2}{|c|}{$\mathrm{D}$} & \multicolumn{2}{|c|}{$\mathrm{N}$} & \multicolumn{2}{|c|}{$\mathrm{A}$} & \multicolumn{2}{|c|}{ SA } \\
\hline 1 & 1 & $0.5 \%$ & 77 & $38.5 \%$ & 17 & $8.5 \%$ & 74 & $37.0 \%$ & 31 & $15.5 \%$ \\
\hline 2 & 0 & $0 \%$ & 18 & $9.0 \%$ & 53 & $26.5 \%$ & 115 & $57.5 \%$ & 14 & $7.0 \%$ \\
\hline 3 & 10 & $5.0 \%$ & 47 & $23.5 \%$ & 25 & $12.5 \%$ & 82 & $41.0 \%$ & 36 & $18.0 \%$ \\
\hline 4 & 2 & $1.0 \%$ & 28 & $14.0 \%$ & 7 & $3.5 \%$ & 85 & $42.5 \%$ & 78 & $39.0 \%$ \\
\hline 5 & 0 & $0 \%$ & 7 & $3.5 \%$ & 13 & $6.5 \%$ & 80 & $40.0 \%$ & 100 & $50.0 \%$ \\
\hline 6 & 0 & $0 \%$ & 2 & $1.0 \%$ & 11 & $5.5 \%$ & 74 & $37.0 \%$ & 113 & $56.5 \%$ \\
\hline 7 & 1 & $0.5 \%$ & 9 & $4.5 \%$ & 14 & $7.0 \%$ & 66 & $33.0 \%$ & 110 & $55.0 \%$ \\
\hline 8 & 6 & $3.0 \%$ & 5 & $2.5 \%$ & 2 & $1.0 \%$ & 47 & $23.5 \%$ & 140 & $70.0 \%$ \\
\hline 9 & 12 & $6.0 \%$ & 13 & $6.5 \%$ & 8 & $4.0 \%$ & 23 & $11.5 \%$ & 144 & $72.0 \%$ \\
\hline 10 & 27 & $13.5 \%$ & 73 & $36.5 \%$ & 25 & $12.5 \%$ & 42 & $21.0 \%$ & 33 & $16.5 \%$ \\
\hline 11 & 8 & $4.0 \%$ & 23 & $11.5 \%$ & 13 & $6.5 \%$ & 106 & $53.0 \%$ & 50 & $7.0 \%$ \\
\hline 12 & 7 & $3.5 \%$ & 35 & $17.5 \%$ & 4 & $2.0 \%$ & 51 & $25.5 \%$ & 103 & $51.5 \%$ \\
\hline 13 & 4 & $2.0 \%$ & 55 & $27.5 \%$ & 26 & $13.0 \%$ & 61 & $30.5 \%$ & 54 & $27.0 \%$ \\
\hline 14 & 10 & $8.5 \%$ & 17 & $8.5 \%$ & 18 & $9.0 \%$ & 88 & $44.0 \%$ & 67 & $33.5 \%$ \\
\hline 15 & 36 & $18.5 \%$ & 27 & $13.5 \%$ & 15 & $7.5 \%$ & 77 & $38.5 \%$ & 45 & $22.5 \%$ \\
\hline 16 & 10 & $5.5 \%$ & 10 & $5.0 \%$ & 1 & $.5 \%$ & 64 & $32.0 \%$ & 114 & $57.0 \%$ \\
\hline
\end{tabular}


Regarding the fourth question of the study (What are the TP overall levels of their computer competence?), results are illustrated in the following table:

Table (5): The TP overall levels of their computer competence

\begin{tabular}{|c|c|c|c|c|c|c|c|c|}
\hline Item & \multicolumn{2}{|c|}{ Much } & \multicolumn{2}{c|}{ Moderate } & \multicolumn{2}{c|}{ Little } & \multicolumn{2}{c|}{ No } \\
\hline 1 & 22 & $11.0 \%$ & 44 & $22.0 \%$ & 47 & $23.5 \%$ & 87 & $43.5 \%$ \\
\hline 2 & 12 & $6.0 \%$ & 53 & $26.5 \%$ & 53 & $26.5 \%$ & 82 & $41.0 \%$ \\
\hline 3 & 2 & $1.0 \%$ & 35 & $17.5 \%$ & 53 & $26.5 \%$ & 110 & $55.0 \%$ \\
\hline 4 & 12 & $6.0 \%$ & 55 & $27.5 \%$ & 40 & $20.0 \%$ & 93 & $46.5 \%$ \\
\hline 5 & 40 & $20.0 \%$ & 44 & $22.0 \%$ & 61 & $30.5 \%$ & 55 & $27.5 \%$ \\
\hline 6 & 36 & $18.0 \%$ & 54 & $27.0 \%$ & 46 & $27.0 \%$ & 64 & $32.0 \%$ \\
\hline 7 & 22 & $11.0 \%$ & 59 & $29.5 \%$ & 69 & $34.5 \%$ & 50 & $25.0 \%$ \\
\hline 8 & 34 & $17.0 \%$ & 39 & $19.5 \%$ & 72 & $36.0 \%$ & 55 & $27.5 \%$ \\
\hline 9 & 24 & $12.0 \%$ & 49 & $24.5 \%$ & 55 & $27.5 \%$ & 72 & $36.0 \%$ \\
\hline 10 & 21 & $10.5 \%$ & 56 & $28.0 \%$ & 68 & $34.0 \%$ & 55 & $27.5 \%$ \\
\hline 11 & 30 & $15.0 \%$ & 67 & $33.5 \%$ & 51 & $25.5 \%$ & 52 & $26.0 \%$ \\
\hline 12 & 42 & $21.0 \%$ & 42 & $21.0 \%$ & 27 & $13.5 \%$ & 89 & $44.5 \%$ \\
\hline 13 & 35 & $17.5 \%$ & 62 & $31.5 \%$ & 54 & $27.0 \%$ & 49 & $24.5 \%$ \\
\hline 14 & 29 & $14.5 \%$ & 38 & $19.5 \%$ & 65 & $32.5 \%$ & 68 & $34.0 \%$ \\
\hline 15 & 43 & $21.5 \%$ & 53 & $26.5 \%$ & 53 & $26.5 \%$ & 48 & $24.0 \%$ \\
\hline
\end{tabular}

Section Four of the study instrument consists of fifteen items on a 4point scale ranging from 1 (no competence) to 4 (much competence). Findings of Table (5) indicate that respondents' computer competence ranged between no to little competence in nine items $(1 ; 2 ; 3 ; 4 ; 8 ; 9$; $10 ; 14$; 15) with an overall $P$ of $60 \%)$ : they have little competence to install software on a computer (67\%), use a printer (67.5\%), use a computer keyboard (81\%), operate a word processing program (66\%), use the Internet for communication (63\%), use the WWW to access different types of information (63.5\%), solve simple problems in operating computers $(62.5 \%)$, create and organize computer files (66.5\%), and remove computer viruses (50.5\%). Findings of Table (5) also indicate that respondents' computer competence is below moderate (average) in three items $(6 ; 7 ; 12)$ with an overall $P$ of $(20 \%)$ : their competence is below moderate to operate a spreadsheet program (55\%), to operate a database program (59\%), and to use computers for grade keeping (58\%). Besides, findings of Table (5) show that respondents' computer competence is moderate (average) in three items $(5 ; 11$;13) with an overall P of $(20 \%)$ : their competence is moderate to operate a presentation program such as PowerPoint (57\%), operate a graphics 
program such as Photoshop (51\%), and select and evaluate educational software $(51.5 \%)$. The majority of the respondents had no or little computer competence in handling most of the computer functions needed by teachers. This means that the weak level of computer competence represents a barrier to the acceptance and utilization of ICT in education in developing countries such as Egypt. This result is congruent with previous related studies that though students have positive attitude towards ICT, their level of commuter competence is weak due to the lack of computer literacy training courses at university before graduation or at school for those who work or the low income for both categories (Pelgrum, 2001 ; Al-Oteawi, 2002 ; Toe, 2008 ; Bordbar, 2010). This also means that it is important to make use respondents' attitudes towards ICT through enhancing their computer competence by preservice and in-service training programs and that higher computer competence fosters the existing attitudes of teachers and eventually make them able to apply ICTs in the classrooms (Bordbar, 2010). Hence, the second hypothesis of the present study that "the TP computer competence ranges between little to no Competence" is accepted.

Regarding the fifth question of the study (What is the extent of TP computer access?), results are illustrated in the following table:

Section Five includes three items to measure the TP frequency rates and places of computer access. Findings of Table (6) reveal that $80 \%$ of respondents get daily (59.5\%) or 2-3 times a week (20.5\%) computer access at home, that $56 \%$ get daily (25\%) or 2-3 times a week (31\%) computer access at school, and $76.5 \%$ never get computer access at Internet cafes (66\%) or get access at them once a month (10.5\%) in case of necessity. Computer access is one of the notorious barriers related to the adoption and integration of ICT in education and, therefore, affects teachers' attitudes towards ICT. Results reveal that majority of respondents have computer access at home and this is the category of students who believe in the significance of ICT in our digital age. So, they develop their computer literacy and skills individually on their own. Still, they lack the knowledge and training of how to employ ICT for teaching and learning purposes. More than half of respondents have computer access at schools and this means that not all teachers can get regular computer access at schools due to the insufficiency of computer sets at schools specialized for teacher use (Walton, 2009; Bordbar, 2010). Besides, majority of respondents never prefer to get computer access at Internet cafes or get once a month if case of necessity. This may be attributed to privacy especially for females and inhabitants of Upper Egypt and to the social and ethical problems that might emerge in 
such places in addition to the money paid for computer sets and for having a drink. Hence, the third hypothesis of this study that "the TP computer access frequency rates range between two to three times a week access to never access" is rejected.

Table (6): Extent of the TP computer access

\begin{tabular}{|c|c|c|c|c|c|}
\hline & 1 & 2 & 3 & 4 & 5 \\
\hline \multirow{2}{*}{1} & 119 & 41 & 19 & 13 & 8 \\
\cline { 2 - 6 } & $59.5 \%$ & $20.5 \%$ & $9.5 \%$ & $6.5 \%$ & $4.0 \%$ \\
\hline \multirow{2}{*}{2} & 50 & 62 & 29 & 26 & 33 \\
\cline { 2 - 6 } & $25.0 \%$ & $31.0 \%$ & $14.5 \%$ & $13.0 \%$ & $16.5 \%$ \\
\hline \multirow{2}{*}{3} & 6 & 14 & 27 & 21 & 132 \\
\cline { 2 - 6 } & $3.0 \%$ & $7.0 \%$ & $13.5 \%$ & $10.5 \%$ & $66.0 \%$ \\
\hline
\end{tabular}

Regarding the sixth question of the study (Are there any differences between male TP and their female counterparts regards to their attitudes towards ICT, their perceptions of computer attributes, relevance, and competence?), results are illustrated in the following table:

Findings of Table (7) indicate that all the calculated t-values are statistically insignificant. This means that that there are no differences between male TP and their female counterparts regards to their attitudes towards ICT in education, their perceptions of computer attributes, relevance to Egyptian society and schools, and competence; students' attitudes towards ICT and their perceptions either positive or negative of computer attributes, relevance to society and schools, and competence either high or low are similar. The reason behind this finding is that students either males or females with positive or negative attitudes and perceptions towards ICT lack the ample income to buy a computer or software or get training courses. Most of them dream of satisfying the basic needs of life such as home, health, clothes, and food and, therefore, are indifferent to be acquainted with computer literacy and application even in their profession as stated earlier in question one. Hence, the fifth hypothesis of the study that "there are statistically significant differences between the mean scores of the computer attitudes, attributes, relevance to society and schools and competences of female students and the mean scores of their male counterparts in favor of male students" is rejected. Compared to previous studies, this finding of the present study agrees with the results of Markauskaite (2006), Al-Rabaani (2008), Toe (2008), Cavas et al (2008), Pelegrin and Badia (2009), Bakr (2011), Rahimi and Yanollahi (2011), Sarfo et al (2011), and EL-Saadani (2012). Still, some other studies did not go in consonance with this finding such as Jamieson-Proctor et al (2006), Vekiri (2008), Gillwald et al (2010), Ozpinar et al (2011), and Mahmoud and Bokhari (2011). Those studies indicated that there are gender differences in relation to ICT aspects. 
Table (7): T-values of mean scores of male TP and their female counterparts regards to attitudes towards ICT, perceptions of computer attributes, relevance, and competence

\begin{tabular}{|c|c|c|c|c|c|c|}
\hline Sections & Gender & $\mathrm{N}$ & Mean & T. value & DF & Significance \\
\hline Attitudes & $\begin{array}{c}\text { Male } \\
\text { Female }\end{array}$ & $\begin{array}{c}83 \\
117\end{array}$ & $\begin{array}{l}76.7470 \\
76.5043\end{array}$ & 0.271 & 198 & Insign. \\
\hline Attributes & $\begin{array}{c}\text { Male } \\
\text { Female }\end{array}$ & $\begin{array}{c}83 \\
117 \\
\end{array}$ & $\begin{array}{l}66.4578 \\
66.7521 \\
\end{array}$ & 0.344 & 198 & Insign. \\
\hline Relevance & $\begin{array}{c}\text { Male } \\
\text { Female }\end{array}$ & $\begin{array}{c}83 \\
117 \\
\end{array}$ & $\begin{array}{l}62.7831 \\
63.3846\end{array}$ & 0.870 & 198 & Insign. \\
\hline Competence & $\begin{array}{c}\text { Male } \\
\text { Female }\end{array}$ & $\begin{array}{c}83 \\
117 \\
\end{array}$ & $\begin{array}{l}41.8193 \\
42.7863 \\
\end{array}$ & 0.742 & 198 & Insign. \\
\hline
\end{tabular}

Regarding the seventh question of the study (Are there any differences between Upper Egypt TP and their Lower Egypt counterparts regards to attitudes towards ICT, perceptions of computer attributes, relevance, and competence?), results are illustrated in the following table:

As is clear in Table (8), findings illustrate that two t-values of the mean scores of the study questionnaire sections (attitudes and competence) are statistically significant $(2.374 ; 1.731)$. This means that there are statistically significant differences in the attitudes towards ICT and in the computer competence between the students of Upper Egypt and those of Lower Egypt in favor of Lower Egypt Students. This finding matches the results of Kyriakidou (1999), Al-Raabani (2006), AlZaidiyeen et al (2010), and Sarfo (2011) and contradicts the findings of Panigrahi (2011). Besides, findings of Table (8) indicate that two tvalues of the mean scores of the study questionnaire sections (attributes and relevance) are statistically insignificant $(0.664 ; 0.073)$. This means that there are statistically insignificant differences in the computer attributes and relevance between the students of Upper Egypt and those of Lower Egypt and this is congruent with the study of Panigrahi (2011). Hence, the sixth hypothesis of the present study that "there are no statistically significant differences between the mean scores of the computer attitudes, attributes, relevance to society and schools and competences of Upper Egypt students and the mean scores of their Lower Egypt counterparts" is accepted in terms of attitudes and competence and rejected in terms of attributes and relevance. These two findings are logical as there are some differences between Upper Egypt and Lower Egypt such as level of education, level of income, and availability of training, and technical support in favor of Lower Egypt. The more presence of those facilities and potentialities in Lower Egypt drives students to have more positive attitudes towards ICT. Positive 
attitudes help them to put ICTs into practice and their competence is more increased. Besides, the perceptions of the students of both Upper and Lower Egypt in terms of computer attributes and relevance are similar (no difference) due to the revolution in ICTs such as TV satellites, mobiles and the Internet, and due to the beliefs and viewpoints regarding ICT that rapidly spread among persons regardless of their geographical location

Table (8): Differences between Upper Egypt TP and Lower Egypt their counterparts regards to attitudes towards ICT, perceptions of computer attributes, relevance, and competence

\begin{tabular}{|c|c|c|c|c|c|c|}
\hline Section & $\begin{array}{c}\text { Geographical } \\
\text { location }\end{array}$ & $\mathrm{N}$ & Mean & $\begin{array}{c}\mathrm{T} . \\
\text { value }\end{array}$ & $\overline{D F}$ & Significance \\
\hline Attitudes & $\begin{array}{l}\text { Lower Egypt } \\
\text { Upper Egypt }\end{array}$ & $\begin{array}{l}100 \\
100\end{array}$ & $\begin{array}{l}77.6400 \\
75.5700\end{array}$ & 2.374 & 198 & Sign. \\
\hline Attributes & $\begin{array}{l}\text { Lower Egypt } \\
\text { Upper Egypt }\end{array}$ & $\begin{array}{l}100 \\
100 \\
\end{array}$ & $\begin{array}{l}66.3500 \\
66.9100 \\
\end{array}$ & 0.664 & 198 & Insig \\
\hline Reler & $\begin{array}{l}\text { Lower Egypt } \\
\text { Upper Egypt }\end{array}$ & $\begin{array}{l}100 \\
100\end{array}$ & $\begin{array}{l}63.1100 \\
63.1600\end{array}$ & 0.073 & 198 & Insign. \\
\hline Competence & $\begin{array}{l}\text { Lower Egypt } \\
\text { Upper Egypt }\end{array}$ & $\begin{array}{l}100 \\
100\end{array}$ & $\begin{array}{l}43.4900 \\
41.2800 \\
\end{array}$ & 1.731 & 198 & $\mathrm{Siq̧}$ \\
\hline
\end{tabular}

Regarding the eighth question of the study (Are there any differences between employed TP and their unemployed counterparts regards to their attitudes towards ICT, their perceptions of computer attributes, relevance, and competence?), results are illustrated in the following table:

Table (9): T-values of mean scores of employed TP and their unemployed counterparts regards to attitudes towards ICT, perceptions of computer attributes, relevance, and competence

\begin{tabular}{|c|c|c|c|c|c|c|}
\hline Section & employment & $\mathrm{N}$ & Mean & T. value & DF & Significance \\
\hline Attitudes & $\begin{array}{c}\text { Unemployed } \\
\text { Employed }\end{array}$ & $\begin{array}{c}86 \\
114\end{array}$ & $\begin{array}{l}76.2093 \\
76.9035\end{array}$ & 0.778 & 198 & Insig. \\
\hline Attributes & $\begin{array}{c}\text { Unemployed } \\
\text { Employed }\end{array}$ & $\begin{array}{c}86 \\
114\end{array}$ & $\begin{array}{c}66.5581 \\
66.6842\end{array}$ & 0.148 & 198 & Insig. \\
\hline Relevance & $\begin{array}{c}\text { Unemployed } \\
\text { Employed }\end{array}$ & $\begin{array}{c}86 \\
114\end{array}$ & $\begin{array}{c}62.9186 \\
63.2982\end{array}$ & 0.551 & 198 & Insig. \\
\hline Competence & $\begin{array}{c}\text { Unemployed } \\
\text { Employed }\end{array}$ & $\begin{array}{c}86 \\
114\end{array}$ & $\begin{array}{c}49.7407 \\
42.0789\end{array}$ & 3.548 & 198 & Sign. \\
\hline
\end{tabular}

Results of Table (9) reveal that the $t$-values of the mean scores of both employed and unemployed respondents in terms of ICT attitudes, computer attributes, and relevance are statistically insignificant. This indicates that there are no significant differences between employed and unemployed participants, meaning that their attitudes towards ICT, their perceptions of computer attributes, and relevance are similar (positive). 
Results also indicate that $t$-value of the mean scores of both employed and unemployed respondents in terms of their computer competence is statistically significant (3.584) in favor of the unemployed with a mean score (49. 7407). Hence, the seventh hypothesis that "there are no statistically significant differences between the mean scores of the computer attitudes, attributes, relevance to society and schools, and competence of employed students and the mean scores of their unemployed counterparts" is accepted in terms of computer attitudes, attributes, and relevance. Both believe that computers widely spread these days, computers are a source of fun and enjoyment, save time and effort, will improve education, and that they would buy a computer if they had money. Still, they have negative attitudes towards the application of ICTs in teaching and learning due to the presence of many obstacles and barriers as stated before. This finding is in consonance with Kyriakidou (1999), Fancovcova (2008), Gulbahar \& Guven (2008), Demirci (2009), Park \& Jeong (2009), Walton (2009), Bordbar (2010), Gillwald et al (2010), Kaur (2011), and Hu (2011). On the contrary, the seventh hypothesis rejected in terms of computer competence, indicating that there a significant difference between employed and unemployed students in favor of the unemployed. This finding is in congruence with Cavas et al (2009) and Rahimi and Yanollahi (2011) but contradicts Toe (2008). The researcher observed that employed students are older (their age ranges between thirty to fifty-five years) than the unemployed students (their age ranges between twenty-two to thirty-five years). This means that age is a significant factor as far as computer competence is concerned. The younger unemployed students have studied computer science as a subject-matter at school and university and this has made them acquire many of computer skills, unlike many of their older employed counterparts who did not study that subject-matter at school or university. Besides, computer literacy in the form of the ICDL certificate (which enhances their computer competence) is a must for university graduates to get a gob to earn one's living unlike the idle employed who already have a job and their living is safe.

\section{Conclusion:}

Based upon the results and discussion of the present study, conclusion is illustrated in the following points:

- Students enrolled at the Educational Qualification Diploma have positive attitudes towards ICT but its application in the classroom is hindered by barriers such as the lack of pre-service and in-service training. So, effective training into the use of ICTs in teaching and learning has to be provided for pre-service and in-service teachers. There are also some other obstacles such as lack of computer sets, 
lack of computer access, lack of ample time, lack of confidence, and low income for teachers. So, some efforts on the part of policy makers have to be exerted to overcome the difficulties that hinder the use of ICT in teaching and learning (Park and Joeng, 2009 ; Awan, 2010 ; Bordbar, 2010 ; Gillwald et al, 2010).

- ICT tools are important as they are necessary for the development of any educational system on ground that they enhance the effectiveness of the teaching/learning process (Adeyemo, 2010). The investigation of teachers' attitudes and perceptions towards ICT is indispensable to the successful implementation of ICT in the teaching/learning process (Bordbar, 2010).

- Greater availability of new teaching technologies such as computer laboratories and training programs better ensure the integration of ICT resources into the lesson plans of EFL teachers (Alshumaim and Alhassan, 2010).

- The relationship between attitudes and perceptions of ICT and computer attributes, relevance, competence is controversial and, therefore, needs more research.

- The relationships between attitudes and perceptions of ICT and computer attributes, relevance, competence and gender, age, geographical location, and employability are still controversial and, therefore, needs more research. This study revealed no differences in addition to other studies such as Markauskaite (2006), Al-Rabaani (2008), Toe (2008), Cavas et al (2008), Pelegrin and Badia (2009), Bakr (2011), Rahimi and Yanollahi (2011), Sarfo et al (2011), and EL-Saadani (2012). Some other studies explored the opposite such as Jamieson-Proctor et al (2006), Vekiri (2008), Cavas et al (2009), Gillwald et al (2010), Ozpinar et al (2011), and Mahmoud and Bokhari (2011).

\section{Recommendations:}

Based upon the results, discussion, and conclusion of the present study, some recommendations are raised as follows:

- More attention and consideration on the part of policy makers is needed for integration of ICT in education by organizing appropriate training courses for prospective and in-service teachers (Al-Zadiyeen et al, 2010).

- Governments should encourage and put incentives to attract local, national, and international bodies, and non-governmental organizations to invest in ICT projects and training for educational purposes at all stages.

- ICT equipment and facilities should be available at all classrooms, at all schools, and at all regions, urban and rural. 
- Local conferences, seminars, and workshops have to held on how to use ICT in classrooms by teachers.

- The relationship between attitudes and gender, age, and geographical location is still a complicated issue and, therefore, needs more research.

- More investigation is required to address the factors that constrain the application of ICT in the teaching/learning situation (JamiesonProctor et al, 2006).

- Teachers' computer skills and knowledge about journals and centers' websites to benefit from in the teaching/learning situation have to be developed (Al-Rabaani, 2008).

\section{Points for Further Research:}

The present study results and conclusion pose the following points for further research:

- To investigate the difference in the attitudes towards ICT implementation in education between students of Arts and Sciences.

- To examine the relationship between attitudes towards ICT and employment/unemployment status of students after graduation.

- To study the attitudes of students towards ICT at the urban and rural areas.

- To replicate the study in other four education qualification centers in West and East Egypt.

- To investigate the relationship between ICT and retention of learning.

- To investigate the relationship between ICT and academic achievement.

\section{References:}

- Alabbad, A. M. (2010). Interactive computer/network-based program for teaching English as a foreign language in the elementary levels in Saudi Arabia. doi:10.1109/CMCS.2011.5945699.

- Albirini, A. (2006). Teachers' attitudes towards information and communication technologies: The case of Syrian EFL teachers. Computers and Education, vol.47, pp.373-398.

- Alkahtani, S. A. (2011). EFL female faculty members' beliefs about CALL use and integration in EFL instruction: The case of Saudi Higher Education. Journal of King Saud University-Languages and Translation, vol.3.

- Al-Oteawi, S. M. (2002). The perception of administrators and teachers in utilizing information technology in instruction, administration, work, and staff development in Saudi Arabia. Doctoral Dissertation, Ohio State University. 
- Al-Rabaani, A. A. (2008). Attitudes and skills of Omani teachers of social studies to the use of computers in instruction. International Journal of Education and Development using Information and (IJEDICT), 2008, Vol. 4, Issue 4, pp.15-34.

- Asabere, S. E. \& Enguash, N. Y. (2012). Use of information \& communication technology (ICT) in tertiary education in Ghana: A case study of electronic learning (e-Learning). International Journal of Information and Communication Technology Research, vol.2, no.1.

- Alshumaim, Y. \& Alhassan, R. (2010). Current availability and use of ICT among secondary EFL teachers in Saudi Arabia: Possibilities and reality. In Z. Abas et al. (Eds.), Proceedings of Global Learning, 2010 (pp. 523-532). AACE. Retrieved from http://www.editlib.org/p/34227.

- Al-Zaidiyeen, N. J., Mei, L. L., \& Fook, F. (2010). Teachers' attitudes and levels of technology use in classrooms: The case of Jordan schools. International Education Studies, Canadian Center of Science and Education.

- Awan, R. N. (2011). What happens to teachers' ICT attitudes and classroom ICT use when teachers are made to play computer games. International Journal of Information and Education Technology. Institute of Development Studies.

- Bakr, S. M. (2011). Attitudes of Egyptian teachers towards computers. Contemporary Educational Technology, vol.2, no.4, pp.308-318.

- Barros, S. \& Elia, B. (2004). Physics teachers' attitudes: How they affect the reality of classrooms and modes for change. Federal University of Rio de Janeiro, Brazil.

- Becta. (2006). Benefits and features of ICT in English. ICT in the Curriculum, Uk.

- Berner, J. E. (2003). A study of factors that may influence faculty in selected schools of education in the Commonwealth of Virginia to adopt computers in the classroom. Doctoral Dissertation, George Mason University. ProQuest Digital Dissertation (UMI, no. AAT3090718.

- Bhati, M. S., Bhati, A. K., \& Kulria, K. K. (2011). Role of ICT in teaching of social studies: Education Archives-ISRJ, vol.1, no.4.

- Bingimlas, K. A. (2009). Barriers of the successful integration of ICT in teaching and learning environment: A review of literature. Eurasia Journal of Mathematics, Science, and Technology Education, vol.5, no.3, pp-235-245.

\section{4}


- Bordbar, F. (2010). English teachers' attitudes towards computerassisted language learning. International Journal of Language Studies (IJLS), vol.4, no. 3, pp.27-54.

- Breckler, S. (1997). Empirical validation of affection, behavior, and cognition as distant components of attitudes. The Blackwell Reader in Social Psychology. UK, Blackwell, pp.221-245.

- Cavas, B., Cavas, P., Karaoglan, B., \& Kisla,T. (2009). A study of science teachers' attitudes towards information and communication technologies in education. The Turkish Online Journal of Educational Technology, vol.8, no.2, pp-20-32.

- Capan, S. A. (2012). Teacher attitudes towards computer use in EFL classes. Frontiers of Language and Teaching, vol.3.

- Demirci, A. (2009). How do teachers approach new technologies: Geography teachers' attitudes towards geography information systems (GIS). European Journal of Educational Studies, vol., no.1.

- Dighe, A. and Reddi, U. (2006). Women's literacy and information and communication technologies: Lessons that experience has taught us. Commonwealth Educational Media Centre for Asia (CEMC).

- Eagly, C. \& Chaikan, L. (1993). The Psychology of attitudes. Fort Work TX: Harcourt Brace Jovanovicly. International Journal of Language Studies, vol.4, no.3, pp.27-54.

- El-Saadani, M. (2012). Teaching staff attitudes towards ICT: Is gender a factor? International Women Online Journal of Distance Education, vol.2012, no.1. Article: 03, ISSN: 2147-0367.

- Fancovicova, J. \& Prokop, P. (2008). Students' attitudes towards computer use in Slovakia. Eurasia Journal of Mathematics, Science, and Technology Education, vol.4, no.3, pp.255-262.

- Fominykh, N. (2004). Using ICT in teaching in teaching and studying English. Education Series, pp.120-125.

- Franzoi, S. (2003). Social psychology. Boston: McGraw-Hill.

- Gillwald, A., Milek, A., \& Stork, C. (2010). Gender assessment of ICT access and usage in Africa. Toward Evidence-Based ICT Policy and Regulation, vol.1, Policy Paper: 51.

- Goktas, Y., Yildirim, Z., \& Yildirim, S. (2009). Investigation of K-12 teachersICT competencies and the contributing factors in acquiring these competencies.The New Educational Review, vol.17, no.1, pp. 276-294.

- Grace, E. \& Harris, H. (2012). Faculty learning community: Redefining literacy for the 21st century. Virginia Commonwealth University Centre for Teaching Excellence. 
- Gulbahar,Y.\& Guven, I. (2008). A survey on ICT usage and the perceptions of social studies teachers in Turkey. Educational Technology and Society, vol.11, no.3, pp.37-51.

- Hennessy, S., Harrison, D., Wamkote, L., \& Tanzania, A. (2010). Teacher factors influencing classroom use of ICT in Saharan Africa. Itupale Online Journal of African Studies, vol.2. pp.39-54.

- Hogg, M. \& Vaughan, G. (2005). Social psychology, Fourth Edition, London $=$ Prentice Hall.

- Hollenbeck, J. E. \& Hollenbeck, D. Z. (2004). Technology to enhance learning in the multi-lingual classroom, East Lasing, MI, Eric document ED490629.

- - Hu, Z. (2009). ICT, EFL teacher development, and the reform of college English in China: An implementation study. PhD thesis, University of Nottingham.

- Jae Shin, H. \& Bae Son, J. (2007). EFL teachers' perceptions and perspectives in Internet-Assisted Language Teaching (IALT). CALLEJ Online, vol.8, no.2.

- Jamieson-Proctor, R. M., Burnet, P. C., Watson, G., \& Finger, G. (2006). ICT integration and teachers' confidence in using ICT for teaching and learning in Queensland State schools. Australasian Journal of Educational Technology, vol.22, no.4, pp.511-530.

- Johns, G. \& Saks, A. (2010). Organizational behavior. Understanding and managing life at work. Sixth Edition, Pearson Education.

- Kaur, A. P. (2011). Pre-service science teachers' attitudes towards the use of selected ICT tools in teaching: An exploratory study. University of Adelaide, Australia.

- Khvilon, E., \& Patru, M. (2002). Information and communication technology in

- Education. UNESCO Division of Higher Education, Paris.

- Mahmoud, A., \& Bokhari, N. S. (2012). Use of information and communication: Gender differences among students at tertiary level. Journal of Educational and Instructional Studies in the World, vol.2, no.4. Article: 12, ISSN: 2146-74-7463.

- Markauskaite, L. (2006). Gender issues in pre-service teachers' training: ICT literacy and online learning. Australasian Journal of Educational technology, vol.22, no.1, pp.1-20.

- Martin, A. (2005). Book review of "redefining literacy for the 21st century". Journal of eLearning, University of Glasgow, vol.2, no.1.

- McKnight, L. (2002). Dancers not Dinosaurs: English teachers in the electronic age EQ, Australia. Summer, 2002. 
- McLeod, S.A. (2009). Attitudes and behavior. Retrieved from: http://www.simplypschology.org/attitudes, html.

- Moore, C. D. (2005). Is ICT used to its potential to improve teaching and learning across the curriculum? CPD: 4484.

- Okigbo, E. C. (2012). Meeting the personal needs of Anambra State Industrialists in Nigeria: A call for mathematics education reform. African Journal of Teacher Education, vol.2, no.2.

- Ozpinar, I., Kutluca, T., \& Arslan, S. (2011). Investigating mathematics teacher candidates' opinions about using information and communication technologies. Cypriot Journal of Educational Sciences, vol.2, pp.75-82.

- Panigrahi, M. R. (2011). Perception of teachers towards extensive utilization of information and communication technology. Turkish Online Journal of Distance Education, vol.12, no.4.

- Park, C. \& Jeong, B. (2009). Implementing computer-assisted language learning in EFL classroom: Teachers' perceptions and perspectives. International Journal of Pedagogies and Learning, vol.5, no.2, pp. 80-101.

- Pelegrin, A. F. \& Badia, A. (2009). Evaluating teachers' gender towards ICT attitudes in vocational schools. The 2nd International Conference of Education, Research, and innovation, 16-18 December, 2009, Madrid, Spain.

- Pelgrum, W. J. (2001). Obstacles to the integration of ICT in education: Results from a worldwide educational assessment. Computers \& Education, vol. 37 (2001), pp.163-178.

- Pickens, J. C. (1998). Attitudes and perceptions. James Madison University in Harrisonburg, Virginia.

- Prestigdge, S. \& Watson, G. (2001). Patterns of pre-service teachers' competencies and what it means for prospective teacher education programs. Paper presented at the AARE Conference Fremantle, 2-6 December, Griffith University.

- Rahimi, A. \& Yanollahi, S. (2011). ICT use in EFL classes: A focus on EFL teachers' characteristics. Journal of English Language, vol.1, no.2.

- Roberts, T. S. (2005). Computer supported collaborative learning in higher education. Hershey, PA: Idea Group Publishers.

- Salamon, D . C. (2002).Technology and pedagogy! Why don't we see the promised revolution? Educational Technology, vol.28, no.1, pp.35-40. 
- Sansanwal, D. N. (2009). Use of ICT in teaching-learning and education.Central Institute of Educational Technology, NCERT, New Delhi, India.

- Sarfo, F. K., Amartei, A. A., Adentwi, K. I., \& Berfo, C. (2011). Technology and gender equity: Rural and urban students' attitudes towards information and communication technology. Journal of Media and Communication Studies, vol.3, no.6, pp.221-230.

- Sinclair, M. J. (General Consultant) (2000). Collins English Dictionary. Fifth Edition. Harper Collins Publishers.

- Toe, T. (2008). Pre-service teachers' attitudes towards computer use: A Singapore survey. Australasian Journal of Educational Technology, vol.24, no.4, pp.413-424.

- Toomey, R. (2001). Schooling issues digest No. 2: Information and communication technology for teaching and learning. Retrieved from: http://www.dest.gov.au/schools/publications/2001/digest/technology.html.

- Vekiri, T. (2008). ICTs and socialization: The role of the school and teachers. A paper prepared for the OECD Expert Meeting on Gender, ICT, and Education, Oslo, 2-3 June.

- Walton, R., Putman, C., Johnson, E., \& Kolko, B. (2009). Skills are not binary: Nuances in the relationship between ICT skills and employability. Annenberg School for Communication, vol.5, no.2, pp.1-13.

- Watson, D. M. (1998). Blame the techno-centric artifact: What research tells us about problems inhibiting the use of IT. In G. Marshal \& M. Ruohonen (Eds.), Capacity building for IT in education in developing countries, pp.185-192. London: Chapman and Hall.

- Wheeler, S. (2000). The role of the teacher in the use of ICT. The National Czech Teachers Conference, University of Western Bohemia, Czech Republic, May, 20.

\section{潾潾潾潾}

